\title{
PENERAPAN TERAPI MUSIK PADA IBU HAMIL HIPERTENSI DI PESISIR PAGARBATU SARONGGI
}

\author{
Ahmaniyah'), Sitti Sarti1), Aulia1), Emdat Suprayitno'), Siti Hatijah'1) \\ 1)Fakultas IImu Kesehatan, Universitas Wiraraja, Madura, Jawa Timur, Indonesia
}

Corresponding author: Ahmaniyah

E-mail : ahmaniyah.fik@wiraraja.ac.id

\section{Diterima 21 November 2021, Direvisi 13 Desember 2021, Disetujui 14 Desember 2021}

\begin{abstract}
ABSTRAK
Di puskesmas saronggi derajad kesehatan ibu dan anak sudah baik tetapi masih ada permasalahan untuk ibu hamil yang mengalami hipertensi dalam kehamilannya, yaitu sekitar $21 \%$ di desa pagarbatu dan desa talang. Dari $31 \%$ ini terbanyak di desa pagarbatu. angka kejadian hipertensi dalam kehamilan tinggi di desa pagarbatu disebabkan karena masyarakatnya dalam mengkonsumsi garam melebihi takaran, menu makanan yang asal-asalan karena rata-rata penduduknya adalah nelayan, dan jika diterapi obat hipertensi tidak dikonsumsi karena akan berakibat buruk pada anaknya, untuk memutuskan masalah, penyelesaian pengobatan alternatif dengan pengobatan nonfarmakologi yaitu dengan menggunakan terapi musik serta melakukan penyuluhan tentang pola makan yang benar ini. Tujuan PKM ini untuk meningkatkan pengetahuan dan menurunkan angka kejadian hipertensi ibu hamil dengan menggunakan metode ceramah dan penerapan terapi musik. Metode : dengan memberikan penyuluhan dan terapi musik, Hasil dari kegiatan penearapan terapi music yaitu: pengetahuan masyarakat (ibu hamil) tentang pola makan meningkat $89 \%$ dan hipertensi yang berhasil mengalami penurunan pada minggu ke 3-4 terapi yaitu rata-rata $110 / 70 \mathrm{mmHg}$.
\end{abstract}

Kata kunci: hipertensi; musik; pengetahuan.

\begin{abstract}
At the Saronggi Public Health Center, the degree of maternal and child health is good but there are still problems for pregnant women who experience hypertension in pregnancy, which is about $21 \%$ in the village of Pagarbatu and Talang Village. Of this $31 \%$, most are in the village of Pagarbatu. The high incidence of hypertension in pregnancy in the village of Pagarbatu is caused by the people consuming salt in excess of the dose, the food menu is careless because the average population is fishermen, and if hypertension medication is treated it is not consumed because it will have a bad effect on the child, to decide the problem, The completion of alternative medicine with non-pharmacological treatment is by using music therapy and conducting counseling about this correct eating pattern. The study aimed in this PKM is to increase knowledge and reduce the incidence of hypertension in pregnant women by using the lecture method and the application of music therapy. Methods: by providing counseling and music therapy, Results: public knowledge (pregnant women) about diet increased by $89 \%$ and successful hypertension decreased in the 3-4th week of therapy with an average of $110 / 70 \mathrm{mmHg}$.
\end{abstract}

Keywords: hypertension; music; knowledge.

\section{PENDAHULUAN}

Wilayah kerja Puskesmas Saronggi

terdiri dari 15 desa, setiap desa mempunyai PONKESDES (pondok kesehatan desa) dengan ditempati oleh bidan, yang mempunyai tugas untuk meningkatkan derajad kesehatan masayakat desa terutama menurunkan angka kematian ibu dan anak. Di puskesmas saronggi derajad kesehatan ibu dan anak sudah baik tetapi masih ada permasalahan untuk ibu hamil yang mengalami hipertensi dalam kehamilannya, yaitu sekitar $21 \%$ di desa pagarbatu dan desa talang. Dari $31 \%$ ini terbanyak di desa pagarbatu. Dilihat dari geografisnya desa pagarbatu termasuk dalam wilayah pesisir yang terdiri dari 4 dusun yaitu longlong, pagarbatu, nangger dan korbi. Hipertensi dalam kehamilan tinggi di desa pagarbatu kemungkinan disebabkan karena letak wilayah berada dipesisir pantai yang masyarakatnya mempunyai pola makan garam yang berlebihan dan walaupun faktor penyebab hipertensi dalam kehamilan tidak diketahui secara pasti. Tetapi dari berbagai penelitian salah satu faktor penyebabnya adalah pola makan.(Kartikasari \& Mauliyah, 2018) Masalah hipertensi dalam kehamilan ini merupakan komplikasi masalah umum yang mempengaruhi 
wanita diseluruh dunia dan merupakan penyebab kematiaan ibu hamil didunia.(Pennings et al., 2011) hipertensi dalam kehamilan berdampak negatif baik untuk ibu dan janin yang dikandugnya.yaitu kematian bayi perinatal, asfiksia neonatorum, gawat janin, solusio plasenta dan perdarahan pascasalin. Dan upaya-upaya yangtelah dilakukan oleh tenaga kesehatan (bidan) yaitu dengan pengobatan konvensional dengan menggunakan obat antihipertensi

Berdasarkan data yang kami dapat dri puskesmas saronggi dan terutama ponkesdes pagarbatu bahwa angka kejadian hipertensi dalam kehamilan tinggi di desa pagarbatu disebabkan karena masyarakatnya dalam mengkonsumsi garam melebihi takaran, menu makanan yang asal-asalan karena rata-rata penduduknya adalah nelayan, dan jika diterapi obat hipertensi tidak dikonsumsi karena akan berakibat buruk pada anaknya, untuk memutuskan masalah ini dan memprioritaskannya yaitu dengan yang pertama kami melakukan penyuluhan tentang pola makan yang benar dikelas ibu hamil dan setelah itu kami melakukan terapi musik, kami memberikan solusi terapi musik karena berdasarkan dari hasil penelitian kami dengan melakukan lieratur riview pada tahun 2019 dari beberapa jurnal bahwa dengan memberikan terapi musik pada ibu hamil yang melakukan hipertensi dapat menurunkan tekanan darah baik sistolik maupun diastolik pada ibu hamil yang mengalami hipertensi. Dan terapi musik ini dengan durasi 30 menit selama 1bulan dapat menunjukkan penurunan ibu hamil yang hipertensi.(Ahmaniyah \& Indriyani, 2020). Tujuan PKM ini untuk meningkatkan pengetahuan dan menurunkan angka kejadian hipertensi ibu hamil dengan menggunakan metode ceramah dan penerapan terapi musik.

\section{METODE}

Peserta dalam kegiatan ini sebanyak 20 orang dan kegiatan pengabdian kepada masyarakat dilaksanakan pada tanggal 13, 20, 27 bulan juni dan 04 bulan juli 2021. bertempat di balai desa pagarbatu. Untuk menyelesaikan masalah yang ada di desa pagarbatu kecamatan saronggi kabupaten Sumenep. maka pengabdian ini menggunakan metode :

\section{Memberikan penyuluhan tentang pola makan.}

Kegiatan ini dilakukan dikelas ibu hamil yang diadakan oleh ponkesdes pagarbatu dengan memberikan materi tentang pola makan yang benar dan nutrisi apa yang dibutuhkan oleh ibu dan janin selama kehamilan sehingga dalam menjalankan kehamilannya nutri ibu dan janin terpenuhi. Dan metode yang digunakan yaitu pertama memberikan liflet pada ibu hamil, kedua ceramah (penyampaian materi), ketiga diskusi yaitu dengan tanya jawab antara ibu hamil dan narasumber terkait dengan materi yang disampaikan, dan yang ke empat adalah evaluasi dari pengetahuan ibu-ibu tentang pola makan yang benar.

\section{Menerapkan Terapi Musik}

Untuk kegiatan ini dilakukan setelah ibu - ibu hamil diberikan penyuluhan, langkah langkah dari kegiatan ini yaitu : pertama mengukur tekanan darah ibu hamil terlebih dahulu untuk menentukan ibu hamil yang mengalami hipertensi atau tidak, kedua membuat group di whatsapp untuk memonitoring ibu-ibu yang mengalami hipertensi dalam memberikan terapi musik selama 1 bulan, ketiga, memberikan terapi musik dengan prosedur ibu hamil dalam posisi telentang dengan diputarkan musik selama 30 menit, keempat, setelah selesai mendengarkan musik selang 10 menit ibu hamil diukur kembali tekanan darahnya dan langsung di isi di lembar observasi, kelima, mengisi musik pada android ibu hamil untuk didengarkan setiap 1 kali dalam 1 minggu dengan durasi 30 menit selama 4 minggu

\section{HASIL DAN PEMBAHASAN}

Tabel 1. Hasil pengbdian masyarakat

\begin{tabular}{|c|c|c|}
\hline $\begin{array}{c}\text { Permasal } \\
\text { ahan }\end{array}$ & Metode & Hasil \\
\hline $\begin{array}{l}\text { Pola } \\
\text { makan } \\
\text { yang tidak } \\
\text { benar }\end{array}$ & penyuluhan & $\begin{array}{l}\text { pengetahuan } \\
\text { responden meningkat } \\
\text { baik sebanyak } 89 \% \\
\text { setelah dilakukan } \\
\text { penyuluhan yang } \\
\text { sebelumnya hanya } \\
5 \% \text { saja. }\end{array}$ \\
\hline $\begin{array}{l}\text { Ketidakma } \\
\text { uan } \\
\text { mengkons } \\
\text { umsi obat } \\
\text { antihiperte } \\
\text { nsi }\end{array}$ & $\begin{array}{l}\text { memberikan } \\
\text { terapi musik } \\
\text { dengan } \\
\text { durasi } 30 \\
\text { menit setiap } \\
\text { hari selama } 4 \\
\text { minggu. }\end{array}$ & $\begin{array}{l}\text { Tekanan darah } \\
\text { responden menurun } \\
\text { secara signifikan pada } \\
\text { minggu ke } 3 \text { dan ke } 4 \\
\text { terapi yaitu rata-rata } \\
110 \text { sistolik dan } 70 \\
\text { diastolik. Dan } \\
\text { responden } \\
\text { mengungkapkan } \\
\text { bahwa merasa lebih } \\
\text { tenang atau rileks } \\
\text { dalam mengahadapi } \\
\text { kehamilannya dan } \\
\text { lebih siap } \\
\text { menghadapi } \\
\text { persalinan. }\end{array}$ \\
\hline
\end{tabular}

Dari tabel diatas dapat dilihat bahwa pengabdian ini berhasil terlaksana dengan baik, karena masalah yang dihadapi mitra teratasi yaitu:tentang kurangnya pengetahuan responden (ibu hamil) dalam pola makan yang 
benar setelah dilakukan penyuluhan tentang pola makan yang benar responden menunjukkan terjadi peningkatan pengetahuan tentang pola makan yang benar sebanyak $89 \%$ saja yang sbelumnya hanya $5 \%$ yang dibuktikan dengan hasil kuesioner yang disebar sebelum penyuluhan responden sebagian besar tidak tahu tentang makanan bergizi, pola makan seimbang dan mereka hanya makan sesukanya. Dan setelah dilakukan penyuluhan tentang pola makan dan dampak apa yang akan dialami oleh ibu dan janin jika mereka mengkonsumsi makanan asal - asalan ratarata responden tanya jawab langsung dan kuesioner responden bisa menjawab bahwa ibu hamil harus memenuhi sumber karbohidrat, protein, lemak, vitamin dan mineral. Pengganti karbohidrat yang biasanya mengkonsumsi nasi dan karbohidrat bisa diganti dengan menggunakan jagung, ubi jalar dan roti, untuk protein hewani menggunakan ikan, ayam, telur dan daging, pengaturan pola makan yang benar dan mengkonsumsi makanan-makanan yang sehat untuk ibu hamil Suprayitno \& Wahid, 2019). hal ini sesuai dengan hasil penelitian ika putri bahwa dengan adanya edukasi gizi pada ibu hamil dapat meningkatkan pengetahuan dan sikap ibu hamil dalam menentukan pola makannya (gizi Kandungannya)(Melati \& Afifah, 2021) hal ini juga sesuai denga penelitian zaki tentang penyuluhan gizi yang disertai dengan simulasi untuk meningkatkan kapasitas sistem imun tubuh pada masa pandemi covid-19(Zaki, 2021)

Selain dengan teratasinya pengetahuan pola makan yang sehat, permasalahan yang kedua juga menunjukkan hasil yang signifikan yaitu terdapat penurunan tekanan darah pada responden yang awlanya rata-rata tekanan darah pada responden adalah $140 \mathrm{mmHg}$ untuk sistolik dan $100 \mathrm{mmHg}$ untuk diastoliknya tetapi setelah dilakukan terapi musik yang dilakukan selama 1 bulan (4minggu) dengan dilakukan rutin 1 minggu 1 kali terdapat penurunan tekanan darah yaitu rata-rata $110 / 70 \mathrm{mmHg}$ pada minggu (terapi) ke 3-4. Dengan adanya penurunan tekanan darah pada responden terapi musik dapat dijadikan terapi non konvensional yang dapat digabungkan dengan terapi konvensional dalm menurunkan tekanan darah pada ibu hamil yang hipertensi. Karena Penggabungan terapi musik dan obat-obatan konvensional tidak hanya memberikan hasil anti-hipertensi, tetapi juga menurunkan detak jantung saat istirahat dan aktivitas saraf simpatik. Penerapan terapi musik pada pasien hipertensi yang telah menjalani operasi caesar juga dapat menurunkan kadar angiotensin II.(Geretsegger et al., 2015) Musik memiliki kekuatan untuk mengobati penyakit dan meningkatkan kemampuan pikiran seseorang. Ketika musik diterapkan menjadi sebuah terapi, musik dapat meningkatkan, memulihkan, dan memelihara kesehatan fisik, mental, emosional, sosial dan spiritual.

Hal ini disebabkan musik memiliki beberapa kelebihan, yaitu karena musik bersifat nyaman, menenangkan, membuat rileks, berstruktur, dan universal. Perlu diingat bahwa banyak dari proses dalam hidup kita selalu berirama. Sebagai contoh, nafas kita, detak jantung, dan pulsasi semuanya berulang dan berirama.

Terapi musik merupakan terapi yang universal dan bisa diterima oleh semua orang karena kita tidak membutuhkan kerja otak yang berat untuk menginterpretasi alunan musik. Terapi musik sangat mudah diterima organ pendengaran kita dan kemudian melalui saraf pendengaran disalurkan ke bagian otak yang memproses emosi (sistem limbik). Terapi musik telah terbukti efektif dalam memanipulasi reaksi stres, kecemasan, rasa sakit, dan ketegangan otot.(Liao, Jiang, \& Wang, 2015)

\section{SIMPULAN DAN SARAN}

Dari hasil pengabdian dapat disempulkan bahwa kegiatan pengabdian ini berhasil mengatasi permasalahan yaitu dengan pengetahuan masyarakat (ibu hamil) tentang pola makan meningkat $89 \%$ dan hipertensi yang berhasil mengalami penurunan pada minggu ke 3-4 terapi yaitu rata-rata 110/70 $\mathrm{mmHg}$. Dengan teratasinya permasalahan mitra maka Sarannya jika melakukan pengabdian kemasyarakat sebaiknya melewati penelitian terlebih dahulu atau literatur jurnal yang lebih banyak supaya hasilnya lebih maksimal.

\section{UCAPAN TERIMAKASIH}

Terimaksih pada universitas wiraraja yang memberikan pendanaan internal dalam kegiatan ini.

\section{DAFTAR RUJUKAN}

Ahmaniyah, A., \& Indriyani, R. (2020). Literatur Review: Terapy Musik Terhadap Hipertensi Kehamilan. Journal Of Health Science (Jurnal IImu Kesehatan), 5(1), 37-41.

Geretsegger, M., Holck, U., Carpente, J. A., Elefant, C., Kim, J., \& Gold, C. (2015). Common Characteristics Of Improvisational Approaches In Music Therapy For Children With Autism Spectrum Disorder: Developing Treatment Guidelines. Journal Of Music Therapy, 52(2), 258-281. 
Kartikasari, R. I., \& Mauliyah, I. (2018). Efektifitas Pemberian Pisang Dan Diit Rendah Garam Dalam Menurunkan Tekanan Darah Ibu Hamil Hipertensi.

Liao, H., Jiang, G., \& Wang, X. (2015). Music Therapy As A Non-Pharmacological Treatment For Epilepsy. Expert Review Of Neurotherapeutics, 15(9), 993-1003.

Melati, I. P., \& Afifah, C. A. N. (2021). Edukasi Gizi Pencegahan Stunting Berbasis Whatsapp Group Untuk Meningkatkan Pengetahuan Dan Sikap Ibu Hamil. Jurnal Pangan Kesehatan Dan Gizi Universitas Binawan, 1(2), 61-69.

Pennings, J. L., Kuc, S., Rodenburg, W., Koster, M. P., Schielen, P. C., \& De Vries, A. (2011). Integrative Data Mining To Identify Novel Candidate Serum Biomarkers For Pre - Eclampsia Screening. Prenatal Diagnosis, 31(12), 1153-1159.

Suprayitno, E., \& Wahid, A. (2019). Pendampingan Tentang Penyakit Hipertensi Dan Perawatan Keluarga Dengan Hipertensi. Seminar Nasional Hasil Pengabdian Kepada Masyarakat, 3(1), 104-106.

Zaki, I. (2021). Peningkatan Pengetahuan Ibu Hamil Melalui Penyuluhan Gizi Dengan Metode Stimulan. Jurnal Of Community Health Development, 2(1), 65-71. 